\title{
Related party transactions under a contingency perspective
}

\author{
Michele Pizzo
}

Published online: 2 June 2011

(C) Springer Science+Business Media, LLC. 2011

\begin{abstract}
Related party transactions (RPTs) are transfers of resources, services or obligations between a reporting entity and a related party (IASB 2009); criteria for a related party definition may significantly differ among the various accounting and governance academic studies and regulatory principles, but they usually depend upon the ability to influ-ence contractual terms and conditions. The topic has been neglected for a long time. In the literature two theories prevail: (a) conflict of interests, considering these dealings as potentially harmful and carried out in the interest of directors; (b) efficient transaction hypothesis, describing them as sound economic exchanges. The paper examines both theories critically through a deductive approach, and also on the basis of their economic rationale. Then, a contingency perspective is suggested, underling how the effectiveness and the efficiency of the proposed solutions are strictly correlated to organizational contexts, institutional environments and governance practices. The study is largely based on a literature review and has different purposes: (a) to shed light on a topic, that, despite its potential impact, has not yet deserved great attention in governance studies; (b) to stress possible inconsistencies in the above mentioned theories, both, to some extent, ideologically biased and unable to offer a proper picture of these heterogeneous dealings; (c) to suggest a more balanced and pragmatic approach, less influ-enced by a suspicious attitude (typical of the conflict of interests theory), possibly more consistent with their economic rationale (as suggested by the efficient transactions hypothesis) as well as social fac-tors and governance practices.
\end{abstract}

Keywords Related party transactions - Contingency theory

M. Pizzo (ه)

Seconda Università di Napoli, Naples, Italy

e-mail: michele.pizzo@unina2.it 


\section{Introduction}

Related party transactions are transfers of resources, services or obligations between a reporting entity and a related party (IASB 2009); criteria for a related party definition may significantly differ among the various accounting and governance academic studies and regulatory principles, but they largely make reference to the ability to influence the dealings' terms and conditions.

Until recent scandals related party transactions did not receive in-depth analyses; academic research mainly focused on different issues and limited attention was paid by regulators and overseers too. Accounting was mainly concerned with potentially biased financial figures; not being carried out at arm's length, they might diverge from market prices (Mason 1979; Brown 1980; Goodman and Lorensen 1985). Meanwhile, in governance studies and codes topics such as board composition and independence, audit committee, directors' remuneration, etc., largely prevailed.

As a consequence, in Europe, until 2002-2003 (and sometimes even afterwards) the topic was largely ignored. In the various European codes and reports on governance, references to related party transactions were lacking, ${ }^{1}$ and-as a matter of fact - the financial disclosure was the only instrument facing both accounting and governance issues. $^{2}$

However, Enron, Adelphia and Parmalat ${ }^{3}$ crises shed light on the inherent risks, as related party transactions emerged as a powerful instrument of financial frauds, shareholders' expropriation, etc., turning the veil from the many relevant loopholes affecting existing requirements.

Such a discovery has obliged regulators and standard setters to strengthen current rules and principles and/or introduce new bans and requirements. A clear shift towards better and more detailed disclosure and the implementation of monitoring procedures (i.e. board approval, independent directors' involvement, external qualified opinions) can be easily observed (i.e. O.E.C.D. 2004) and considered an effective strategy (Djankov et al. 2005).

Not surprisingly, related party transactions are now explicitly mentioned and disciplined in most of the recent rules or codes. ${ }^{4}$

\footnotetext{
${ }^{1}$ In France, a general disclosure requirement could be found as well as shareholders approval, while it was limited to transactions of particular importance in Spain. In other cases, approval by the board of directors was required, and disclosure limited to transactions not approved by the board (Italy). In Germany, operations not carried out at normal market conditions were prohibited for both Management and Supervisory Boards. Later on, these conditions were smoothed and only compliance with normal industry standards, including advance approval by the Supervisory Board, was required.

${ }^{2}$ In actual fact, the information required was both a proxy of potential accounting bias ad a tool for monitoring purposes. Disclosure requirements are still common in countries with larger and more successful financial market, confirming their utility.

${ }^{3}$ See Melis (2005).

${ }^{4}$ Moreover, the implementation of Directive 2006/46 will probably contribute to greater harmonization. The expected changes will probably focus on: (a) the reference to IAS 24 for "related party" definition; (b) a more detailed disclosure (amount, nature and any other information that might by necessary); (c) scope limited only to relevant transactions not carried out at normal market conditions (market conditions are not however limited to the price but embraces also the economic reasons supporting the dealing). However, such a process is still on-going and its impact cannot yet be properly examined.
} 
However, despite growing attention, the discipline is still a patchwork with many inconsistencies and loopholes. ${ }^{5}$ Sometimes-as in Germany-it is still part of the conflict of interests discipline.

Contemporarily, the substantial anecdotal evidence, provided also by scandals like Enron etc., increased the suspicious attitude and the negative common perceptions, generally accompanying these operations, that became more widely and profoundly accepted.

In the literature two theories prevail: (a) conflict of interests. These dealings are considered as potentially harmful and carried out in the interest of directors; (b) efficient transaction hypothesis, considering them as sound economic exchanges (Gordon et al. 2004a, b).

Review of the literature and the regulatory framework does not provide a clear and definite picture, but it supports many shades of opinion and reveals both theoretical and operational open issues, deserving further and more detailed analysis.

This paper carries out a critical survey of the literature on the issue and attempts to examine the economic rationale behind related party transactions (hereinafter "RPTs"). Upon these premises and also according to their consistency with prevailing social conditions and the corresponding governance models, some possible solutions are discussed and supported.

The study, with a deductive methodology, is largely based on a literature review and has different purposes:

- to shed light on a topic, that, regardless of its relevance, does not play a significant role in governance studies;

- to stress possible inconsistencies in the above mentioned theories, both, to some extent, ideologically biased and unable to offer a proper picture of these dealings;

- to suggest a more balanced and pragmatic approach, less influenced by a suspicious attitude (typical of the conflict of interests theory), possibly more consistent with their economic rationale (as suggested by the efficient transactions hypothesis) as well as social factors and governance models.

The remainder of the paper is organized as follows. Through a review of the academic literature, Sects. 2, 3 and 4 carry out a critical analysis of both the conflict of interests and the efficient transactions hypothesis. Section 5 introduces a different conceptual framework, stressing the role that a contingency perspective might play in order to draw a clearer picture of RPTs' issue. Sections 6 and 7 describe how the adoption of such a more pragmatic approach could increase the effectiveness and the efficiency of RPTs regulations. Section 8 concludes with a summary of the basic results and a discussion of potential implications for researchers, standard setters and regulators.

\footnotetext{
5 A definition of related party transactions is often lacking, and when present is not comparable. Disclosure requirements, instead, are still largely prevalent, but national legislation and domestic rules significantly differ between countries. Finally, monitoring procedures are extremely fragmented.
} 


\section{Related party transactions as conflict of interests: literature review}

The topic has always been studied in the literature according to two different theories:

(a) conflict of interests;

(b) efficient transaction hypothesis.

According to the former, related party transactions may imply moral hazard and may be carried out in the interest of directors in order to expropriate wealth from shareholders. By contrast, the latter considers these dealings as sound business exchanges fulfilling economic needs of the firm.

Academic research consistent with the former approach has thrown light on the drawbacks associated with related party transactions:

(a) weakening corporate governance. Related party transactions may undermine non-executive directors functions, turning them into affiliated or "grey" directors, classified as non-independent outside (Denis and Sarin 1999; Klein 2002; Vicknair et al. 1993; Weisbach 1988), closer to dependent directors. Furthermore, weaker corporate governance makes these transactions more likely to occur, while board independence and their lower probability are positively associated (Kohlbeck and Mayhew 2004; Gordon et al. 2004a, b);

(b) earnings management (i.e. "a purposeful intervention in the external financial reporting process, with the intent of obtaining some private gain"; Schipper 1989). Directors have incentives to manage earnings to increase or legitimate their perquisites or to hide such wealth expropriation. Related party transactions may turn out to be a useful tool for managing earnings (Jian and Wong 2008; Aharony et al. 2005), operating results and achieving ROE or other targets (i.e. avoiding delisting, new equity issue placement) (Jian and Wong 2003; Ming and Wong 2003);

(c) tunneling, i.e. wealth transfers out of a company for the benefit of shareholders with a controlling interest (Johnson et al. 2000). A company may pay a related party transaction above market prices or pay market prices for goods or services of inferior quality. ${ }^{6}$ Such a phenomenon does not necessarily imply opportunistic behaviour, but may be due to an overconfident approach or biased judgement (for instance, overestimating one's relatives, Ryngaert and Thomas 2007). Transfer of assets and profits, although common in developed countries, becomes more relevant and frequent in emerging economies where external markets are inadequate or corporate governance rules are lacking and, presumably, less effective (Jian and Wong 2004; Jiang et al. 2005);

(d) employment of relatives in family firms. A director can be appointed or promoted owing to his family influence over the company;

(e) misleading statement. Many studies provide evidence of their role in many financial crises (Swartz and Watkins 2003; Tague 2004) and in the achievement of specific aims (Erickson et al. 2000). Moreover, apart from

\footnotetext{
${ }^{6}$ Relations between ownership structure and tunneling has been examined by Lemmon and Lins (2003); Bertrand et al. (2000) and Bae et al. (2002); Jiang et al. (2005).
} 
these cases, these transactions are generally regarded as less reliable than arm's length ones.

Because of these factors, related party transactions may be associated with abnormal stock returns (Cheung et al. 2006), firms' poor performances (Chen and Chien 2004) or lower value (Gordon et al. 2004a, b; Jian and Wong 2004). ${ }^{7}$

The previous circumstances support the idea that these transactions represent a conflict of interest (conflict of interest hypothesis) and that they are inconsistent with shareholder wealth maximization (Emshwiller 2003). To this extent, such a view encompasses agency issues and is consistent with an agency prospective (Berle and Means 1932; Jensen and Meckling 1976) where owners face moral hazard (lack of effort or misuse of company resources) and adverse selection by the CEO (misrepresentation of ability). Thus, risk sharing policies, monitoring, information systems are adopted and, in particular, mechanisms like CEO compensation and board structure are suggested. Once framed in such a context, related party transactions may imply the misuse of firm resources (moral hazard) and the misrepresentation of private information (adverse selection) too: their potential harm in eluding alignment mechanisms, like CEO compensation and board composition, is increasingly perceived. Moreover, the potential bias in financial statements, with a negative impact on their reliability and relevance, introduces further uncertainty and weakens the effectiveness of contracts aiming at reducing agency conflicts.

In particular, according to agency theory (Fama 1980; Fama and Jensen 1983) an optimal board composition requires both executive members as well as external (non-executive) directors, thus monitoring becomes even more crucial when nonexecutive directors are involved (Gordon et al. 2004a, b).

Not surprisingly, these findings contributed in definitely shifting opinion in favour of the view that related party transactions represent conflict of interests, compromising directors' independence and monitoring functions, potentially serving deceptive and fraudulent purposes. Indeed this idea, has always largely prevailed, but corporate collapses and, to some extent, literature provided ultimate evidence of possible abuses and, moreover, a difficult point to challenge.

The risks of harm to company shareholders through self-interested decisions by directors, spoiling corporate wealth, are often stressed in business press and in regulators' positions, thereby favouring widespread acceptance of the prevailingly negative meaning of the term.

The ability to influence the counterpart even in contrast with its own interests, the departure from terms applied in relationships with third parties and, last but not least, the potential wealth transfers are often recalled by S.E.C. and F.A.S.B. (F.A.S. 57).

The following quotation from the $2008 \mathrm{CONSOB}^{8}$ draft on related party transactions enlightens as to the cautions and adverse approach lying behind the suggested changes: "In general, ..., the existence of companies' interest in carrying

\footnotetext{
7 Equity investors discount equity prices in order to account for potential agency issues (Claeessens and Fan 2002) and related party transactions have a clear agency impact.

8 Italian Stock Exchange Commission.
} 
out related party transaction cannot be a priori excluded. In a few cases, they may be seen as efficient transactions ..." "9 Their economic soundness is not, in principle, rejected, but is clearly limited to few cases, and even then the asymmetrical information among insiders and outsiders leads to stricter regulation.

Indeed, definitions like "accounting minefields" (Sherman and Young 2001) clearly express the general mood.

Not surprisingly, growing concern for abuses, lack of information symmetry, negative influence on directors' independence and integrity and weakening of monitoring functions is warranted among overseers and standard setters. In actual fact, newly introduced rules or principles, aimed at improving disclosure and implementing more effective monitoring procedures, represent a clear attempt to balance the above-mentioned risks and perceptions.

Specifically, solutions enhancing conflict of interest provisions, such as:

- monitoring procedures like board approval, independent directors involvement, audit committee evaluation, external independent opinion, assembly approval;

- increasing disclosure concerning subjects, type of transactions, amount, terms and conditions, alignment with market conditions, etc. In fact, investors can analyse the possible expropriation and weight it in order to discount equity prices (Barth 1994; Wilkins and Zimmer 1983; Harris and Ohlson 1987; Sami and Schwartz 1992);

- ban on some operations (i.e. employment-loans, prohibited by Sox in 2002.

Gain wide support and seem unavoidable measures to cope with the perceived risks.

At the same time, the consistency of the above-mentioned measures with agency theory principles, that suggests monitoring, incentive alignment and control of managers to minimize the agency problems (Tosi 2008), can be easily perceived.

However, costs of monitoring and of reporting complexity increase sharply because of the former measures and they add on the potential economic costs associated with related party transactions (due to wealth transfers, earnings management, etc.) as well as the associated opportunity costs (often widely neglected). The overall resulting negative impact on performance can be legitimately presumed and could improperly represent a cage for this sort of transaction, to which recourse may be limited.

\section{The conflict of interests theory: a critical perspective}

The conflict of interests theory seems probably more sensitive to social needs, such as minority protection and capital market fairness and efficiency. Not surprisingly, its solutions are coherent with the growing concern for these dealings and the political climate around the issue. It could be argued that, to some extent, this perspective offers a "political excuse" to legitimate more binding, disclosure and monitoring requirements.

\footnotetext{
$\overline{9}$ Courtesy translation and emphasis added, par. 10.
} 
However, this approach is weakened by significant drawbacks or loopholes, some of which are hereinafter briefly examined and that are mainly related to conflicting empirical evidence and its inability to reflect the actual economic rationale behind these dealings.

\section{(a) Empirical evidence}

Empirical evidence neither always nor consistently accomplishes the expected outcomes. As previously seen, the literature supports contradictory conclusions too and gradually reveals, instead of a black and white picture, a multicoloured portrait, introducing distinctions and warnings which call for specific treatment. The idea that related party transactions are not all the same and only some categories may be considered harmful is slowly emerging:

- the assumption that their presence might elevate the risk of fraud has not found supporting evidence (Bell and Carcello $2000^{10}$ );

- ex-ante transactions (i.e. carried out before listing or the acquisition/merger making both parties related) and $\mathrm{Q}$ ratios and operating performance are not inversely related, while ex-post ones play a negative influence on firm value and performance and are associated with the likelihood of entering financial distress or de-listing (Ryngaert and Thomas 2007);

- fixed-rate loans from related parties are positively related with earnings management, but no evidence can be provided for other dealings, thereby supporting the overall conclusion that related party transactions do not necessarily imply earnings management (Gordon and Henry 2005);

- complex dealings or transactions with investments are positively related as far as both excess compensation and future shareholders' returns are concerned, but simple transactions (apart, however, from loans to related parties) may be negatively associated with future returns (Kohlbeck and Mayhew 2004). Moreover, loans at below market rates let low-ownership directors increase their shares, aligning their interests with those of shareholders and, therefore, reducing agency conflict (Shastri and Kahle 2004).

It is therefore clear that empirical evidence does not always support the conflict of interests theory premises, while legitimates the assumption that related party transactions can pursue fair and economically sound business purposes, as hereinafter described.

(b) Related party transactions and their economic rationale

The economic features of many related party transactions do not consistently fall within the tight boundaries of conflict of interests theory and can even struggle with it.

- tunneling does not necessarily imply the opportunistic wealth expropriation pursued by directors and/or controlling shareholder. It might be part of a tax strategy aimed at reducing the overall effective tax rate of MNE or

\footnotetext{
10 The authors compared companies committing or not committing fraud and did not find any statistically significant difference in related party transactions between them.
} 
shareholders; for instance, interest deductions on intra group loans from tax haven countries or costs charged to companies located in jurisdictions with higher tax income rates (usually through licensing of intangible property, SPE, sale of goods and services) shift income, raising concern among tax authorities, but can be classified as neither self-interested decisions by directors nor necessarily harmful to minority shareholders;

- a controlling shareholder may use private funds to temporarily support a company in financial distress in order to save it from bankruptcy. This sort of tunneling, known as "propping" in literature (Friedman et al. 2003), is aimed at reviving the firm and preserving controlling shareholder options to expropriate (tunneling) in the future and receive their share of profits. Propping that is positively related to pyramidal structures (Friedman et al. 2003), and is often associated with tunneling (Riyanto and Toolsema 2004), is beneficial to minority interests, acting as a sort of insurance for them.

An underlying implicit assumption behind conflict of interests theory is that related party transactions could have been carried out with a third party at arm's length conditions, that is in a market exchange. The influence of neo-classic economic paradigms is clear. Once assumed that an efficient market exists, where rational players may exchange their production and exploit the best available conditions, internal dealings must be regarded with suspicion; their economic rationale as well as their conditions are inevitably questioned.

Unfortunately, this approach is mainly theoretical and conflicts with the actual business world.

A market may not exist (technical, logistic, economic or political restraints or limitations do not allow for recourse to it or make the choice a deception), or it can be intentionally left apart as exchanges within the network established with related companies or the group itself may be more convenient, because they reduce transaction costs or offer new opportunities.

Joint ventures among companies with different, interdependent skills may favour innovative products (or processes) or, by adopting a cost-cutting strategy, retain profitability: for instance, in order to face sharp fuel price increases, partners may smooth competition practices among them, combine their production process and offer a common service or product through a joint venture. The transactions among the joint venture and its partners are consistent with a sound business strategy and represent a main goal of the new entity; they create an internal market where better business conditions or opportunities are available.

One outstanding example could be offered by Macquarie Group Ltd, an Australian financial institution, well-known for privatization and securitization of public infrastructure (toll roads, airports, ports, water utilities, etc.). Investment funds grant the financial support for its investments; specifically, assets are grouped according to their nature or location and placed in a single fund that can be private or public traded.

Macquarie manages the different funds, receiving fees for asset management, performance bonus and, in the event of listing, underwriting fees too. It is quite clear 
that funds are projected, created and managed in order to be the arms of Macquarie Group Ltd.

Does an alternative market for these funds exist (for instance, for a Korean fund)? Even so, investors opted for Macquarie. Legitimate concern for external investor protection $^{11}$ cannot question the economic soundness of these dealings.

This business model is common to other competitors too, and criticism coming from the market made a growing number of these funds remain private rather than being listed.

The examples provided and the above-mentioned studies clearly suggest that these dealings may also reflect, to a large extent, a sound business policy and be carried out in the best interests of the companies involved.

\section{The efficient transaction hypothesis: literature review and critical analysis}

In contrast with the previous approach, the efficient transaction hypothesis assumes that related party transactions represent sound business exchanges, efficiently fulfilling underlying economic needs of the firm.

Therefore, they do not harm the interests of shareholders and emerge as an efficient contracting arrangement where incomplete information there is. Moreover, possible benefits may be:

- contracting parties' representatives appointed as board members facilitate the achievement of better coordination of the different activities, quicker feed back or more insights;

- deeper reciprocal knowledge as well as greater familiarity can justify transactions that are not feasible at arm's length or create more convenient terms and conditions for both parties;

- hold up problem may be mitigated;

- these transactions may also supplement CEO and director cash remuneration or compensate them for increased risk.

The view of related party transactions representing internal dealings, alternative to contractual or market exchanges, able to reduce transactions costs and overcome difficulties impairing production is consistent with the transaction cost theory (Coase 1937; Williamson 1985) and supporting evidence has been provided by many studies (Fan and Goyal 2006).

In particular, in institutional contexts without efficient capital, labour and product markets, like many developing economies, information and agency problems, as well as market imperfections, increase risks associated with firm activity, while group structures and internal dealings may provide a better allocation of financial resources, economies of scale, easier access to finance, more opportunities, increased influence, etc.

\footnotetext{
11 The company says that fees are benchmarked to the market or subject to external review and that fund management is autonomous.
} 
Therefore, internal capital markets may be created with beneficial effects for the entire group when external funds are scarce and uncertain (Khanna and Palepu 1997); scale and scope of the groups permit difficulties impairing production in emerging countries to be overcome and make investment in these regions more likely and profitable (Fisman and Khanna 2004); sharing technological skills and advertising, associated with available group financial resources, contributes to profitability, supplementing inefficient capital markets and reducing transaction costs (Chang and Hong 2000; Moscariello 2007).

Nevertheless, evidence is not yet decisive (Khanna and Palepu 2000) and the possibility of wealth transfers through internal dealings (Chang and Hong 2000) is not excluded. Moreover, agency issues still play a role in shaping benefits and costs of group affiliation and related problems reduce the beneficial effects deriving from internal markets (Claeessens and Fan 2002; Claessens, et al. 2006).

Unfortunately, the efficient transaction approach does not seem a persuading alternative to the conflict of interests theory.

Empirical evidence is not always supportive of its premises and, indeed, the idea that related party transactions always satisfy economic needs might be quite naïve.

Risks associated with these dealings, although only potential and not common to all the cases, can be neither ignored nor neglected. They may always represent a harm for shareholders and undermine confidence in the capital market. Not surprisingly, the rules affecting related party transactions disclosure and monitoring have been largely influenced by the conflict of interests theory and the agency perspective, that provided some solutions to this risk, while the efficient transaction approach has been of very little influence.

\section{RPTs under a contingency perspective: some preliminary guidelines}

Both the above-mentioned research methodologies are affected by inconsistencies or deficiencies and, in providing almost diametrically opposite interpretations, they are unable to cope with different kinds of possible cases.

Indeed, both schemes are methodologically biased. The possibility that the examined theories (conflict of interests and efficient transaction hypothesis) could coexist is never taken into account. Transactions between related parties are abstractly analyzed through one of the theoretical framework, without making any reference to specific organization or institutional contexts that might affect the nature of similar operations. Consequently, they classify related party transactions only according to some of their features (risks in the former approach, benefits in the latter), pointing out regulatory implications that result inevitably unbalanced as stressing just one side of the coin.

Moreover, the article published so far on RPTs rarely consider possible complementarities or conflicts between corporate governance practices, so threatening the effectiveness and the efficiency of RPTs rules.

As a matter of fact, in adopting a deductive approach, they simply set a range with increasing disclosure and monitoring requirements at one end and a substantial business freedom at the opposite end. The difference is not only theoretical but 
conveys associated costs and risks. In fact, by leaving the efficient transaction approach and moving towards the conflict of interests, one introduces increasing agency costs and does not necessarily imply better monitoring results; greater disclosure and more detailed monitoring procedures do not always mean better information and/or more effective control (Fig. 1).

Probably, the time has come to go beyond these frameworks and adopt a more pragmatic and systematic approach, where related party transactions are adequately framed and considered as they actually are, that is dealings that may:

- fulfil sound business needs as well as be intended for deceptive or fraudulent purposes; and

- interact with and be influenced by other contextual factors (like geographical and cultural differences, corporations' industry and size) and governance mechanisms (like board approval, independent directors' involvement, external appraisal, etc.).

For this reason, any a priori theoretical choice will always be biased and lead to unsatisfactory disclosure or monitoring solutions. In contrast, the search for more effective measures-able to protect investors without imposing inappropriate or excessive restraints over sound economic dealings - cannot neglect the role played by firm's internal and external factors in shaping nature and purposes of RPTs.

In other terms, by embracing a contingency approach (Aguilera et al. 2008; Dedman and Filatotchev 2008; Huse 2005), potential risks and benefits associated with specific categories of RPTs should be weighted, taking into account the

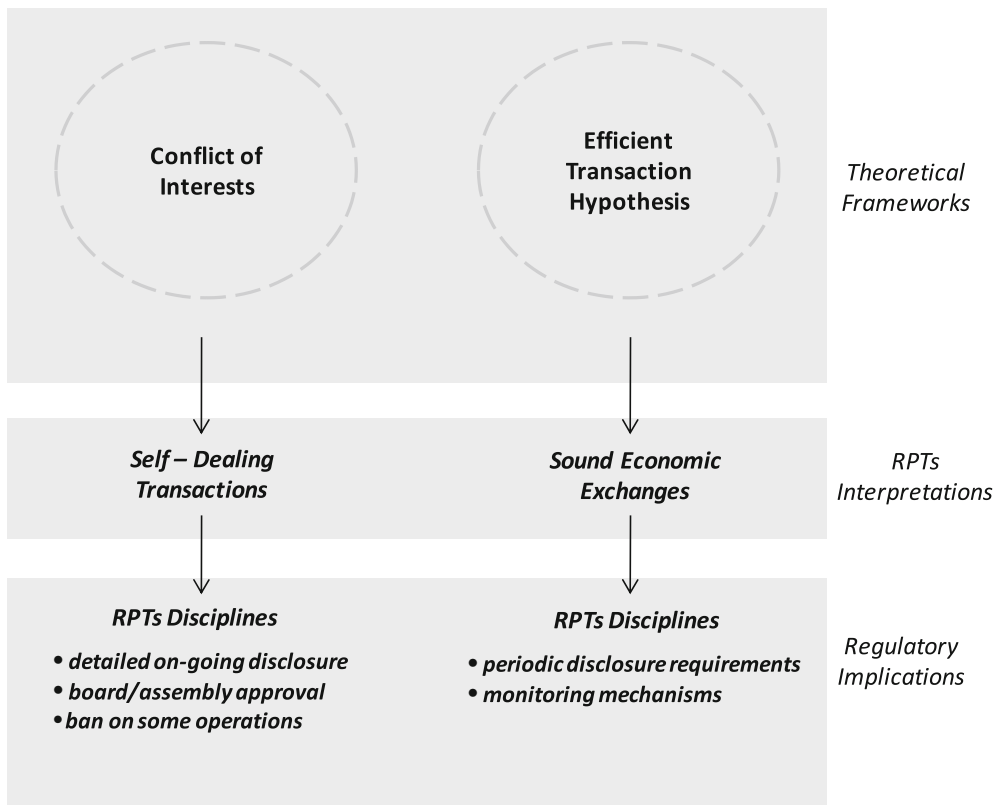

Fig. 1 Traditional research methodology on RPTs 
existing relations with other contextual factors and governance mechanisms, and adapt requirements accordingly.

Indeed, the academic literature has already stressed as a deep investigation on corporate governance issues cannot neglect the patterned variation in corporate governance caused by peculiarities in both organizational contexts and institutional environments. Recent studies, for example, have attempted to explain the dynamic of corporate governance over the company life cycle (Filatotchev et al. 2006; Filatotchev and Wright 2005; Johnson 1997) as well as the diversity of corporate governance arrangements across countries (Gospel and Pendleton 2005; Bruce et al. 2005; Buck and Shahrim 2005; Schmidt and Spindler 2004; Aguilera and Jackson 2003). Moreover, the usefulness to consider complementarities between corporate governance practices in order to assess the effectiveness and the efficiency of corporate governance models has also been suggested (Hoskisson et al. 2002; Rediker and Seth 1995; Walsh and Seward 1990). According to this research stream, corporate governance practices has to be considered as a "bundle" of instruments whose ability to align stakeholders interests is strictly correlated to their strong interrelations. The usefulness of a corporate governance mechanism may depend on the presence of other governance factors, making some combinations more effective than others.

For this reason, building on Aguilera et al. (2008) paper, this article proposes a novel contingency-based framework, examining causes and consequences of RPTs in the light of the influences exercised by:

- organizational contexts and social factors;

- complementarity/substitution between governance factors.

As summarized in Fig. 2, the adoption of a contingency perspective implies an overlap of the theoretical frameworks represented by the conflict of interests and the efficient transactions hypothesis. Consequently, the interpretations on RPTs have to be filtered through a deep analysis of the contingent factors concerning specific organizational contexts and institutional environments, finally proposing regulatory implications in accordance to the "bundle" of the existing governance practices.

The next sections firstly highlight how country and firm-level contingencies might influence the effectiveness of the proposed RPTs disciplines. Secondly, the importance of considering the overall "bundle" of corporate governance practices in order to assess the effectiveness/efficiency of a specific RPTs rule is stressed, underlining how the negative consequences of potential counteractions carried out as a response to a stricter discipline affect the overall judgment of policy makers and regulators' activity.

\section{The role of organizational contexts and social factors}

Preference for a more inductive and systemic approach, where related party transactions are not considered separately from other related governance issues, imply a previous in-depth analysis of the existing organizational context and socioeconomic conditions. 


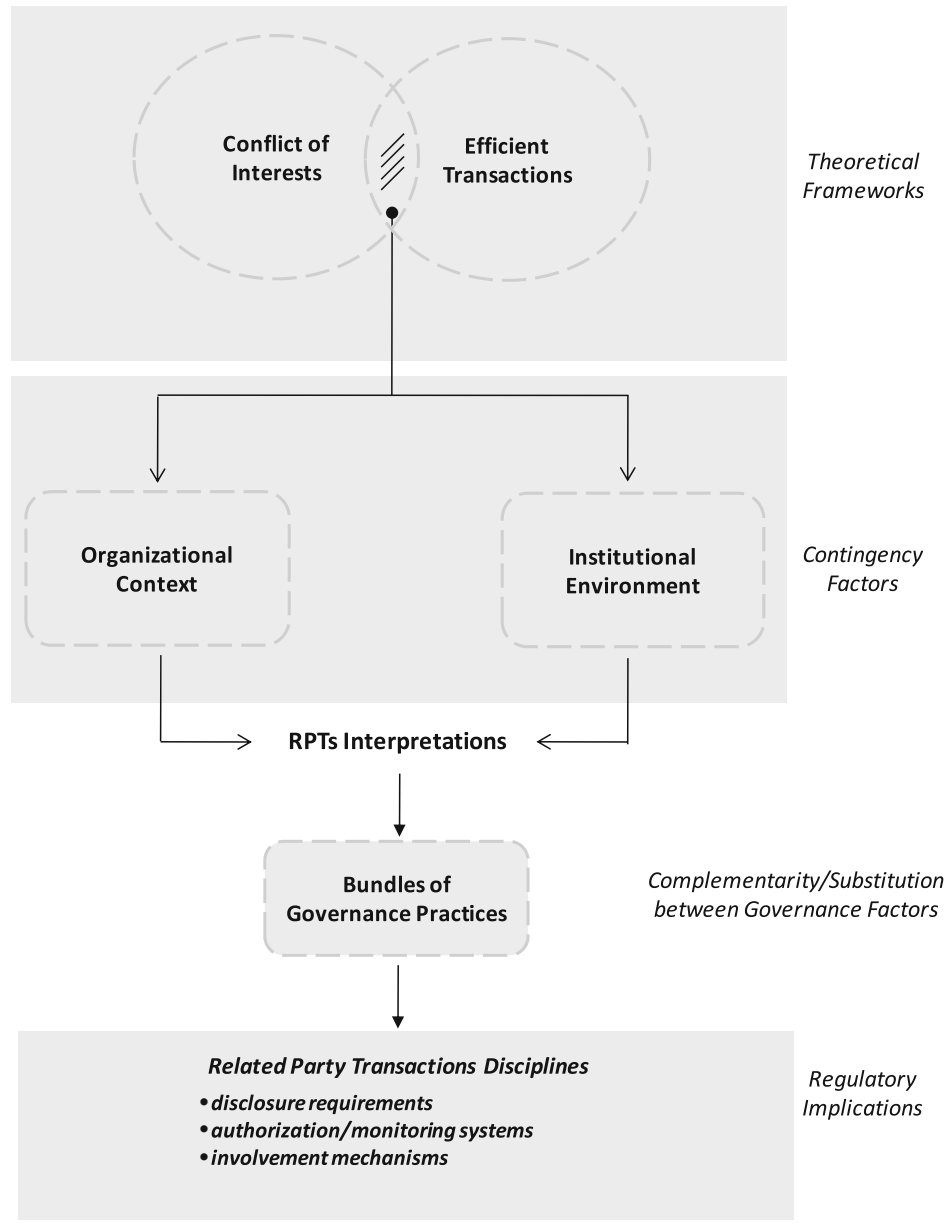

Fig. 2 RPTs under a contingency perspective

In actual fact, even where a negative association with firm value, performance and governance has been found, a straight relation cannot be maintained; concomitant circumstances can play a role, too. A poor business performance can be explained through the combination of related party transactions, weak corporate governance and monitoring (Chen and Chien 2004). Instead of being an independent variable, related party transactions not fulfilling sound economic needs, stem from a mixture of opaque control, weak protection of external shareholders, inadequate disclosure and concentrated ownership (Jesover and Kirkpatrik 2005). Consistent with this different perspective, they become a dependent variable and if they are no longer considered a cause but a result of former circumstances, analysis has to be focused on them, too. Moreover, any solution cannot disregard other related governance issues and has to be built up in parallel. 
As already mentioned, social factors also play an important role in the issue, making these exchanges and their implications peculiar in each nation. Business and governance models vary among countries. Europe, USA and developing economies may not be considered similar. Thereby, universal solutions are not feasible (Coffee 2005). Specifically, conclusions supported by empirical evidence in one country cannot be automatically or implicitly translated to others or considered as generally valid. Unfortunately, many academic studies are based on USA or developing countries data (prevailingly China and India), but the European market largely differs and results are hardly comparable.

Some examples will probably contribute to clarifying the point.

Conflict between firm managers and dispersed shareholders is a common condition in USA and Japan and is also the main issue in the agency perspective. Thus, stress is placed much more on monitoring managers and the transactions they are involved in, and shareholders are considered as one group. Conversely, this feature is relatively unusual in other European and Asian markets, where control is exercised through large holding blocks. ${ }^{12}$ The major issue here is minority (and, as a broader category, investors) protection from majority shareholders (Enriques and Volpin 2007; Di Carlo 2007). Opportunistic behaviour by directors is not a significant risk; they are appointed by controlling shareholders and are often aligned with them. Information asymmetry emerges probably between minority and majority shareholders. ${ }^{13}$ Both a USA based approach and an agency perspective would be misleading.

An approach influenced by the USA experience may imply the risk to divert control procedures from their proper scope, focusing on the wrong players, neglecting more relevant dealings and using inadequate tools.

In a European framework controlling shareholders and other issues deserve major attention.

Disclosure improvements may not suffice, as controlling shareholders do not need to be informed or to control managers; whereas minority shareholders, apart from suing company and/or directors in extreme but rare cases (frauds are neither frequent nor usually disclosed), can exert limited impact. They have restricted access to internal information and cannot influence directors' decisions. Moreover, disclosure provides information only for historical events; any damage, whether ascertainable or not, has already happened. Only monitoring procedures can prevent potential losses. However, in order to be effective, they require independent directors' involvement (detailing the information to be provided and its timeliness, their role in the decision-making process and the possibility of obtaining qualified external expertise and appointing their own trust professionals) but they must be genuine independent directors. Otherwise, the vicious circle between directors and majority shareholders will not be broken. Thus, the ability of minority shareholders to appoint independent directors and/or the presence of high-profile independent directors as well as their skills become central issues.

\footnotetext{
12 Especially, in non-common-law countries (La Porta et al. 1998, 1998).

13 In particular in non-common-law countries corporate governance disclosure is lower than in commonlaw countries (Bauwhede and Willekens 2008).
} 
However, genuine independent directors are rare. They are often associated with the controlling shareholder and/or the $\mathrm{CEO}$ and recruited through personal contacts or friendships (Mork 2008). Moreover, their subservience may be reinforced by other factors (i.e. loyalty, duty, group policy, reciprocal favour trading) that cannot be easily overcome (Mork 2008).

New requirements without mechanisms that guarantee the appointment of truly independent directors or that strengthen their independence will lose their expected impact. Unfortunately, fear for such risk is not a theoretical concern. Recent changes in governance codes and regulations, devised to cope with the issue, neglect the problem. More detailed disclosure and new requirements regarding independent directors and/or audit committees are the solutions provided but no corresponding emphasis is placed on directors' independence and their skills.

A final example may be provided by Asia. Governance in Asian markets is usually weaker and protection for the minority shareholders limited; in countries where, in the absence of enforcement actions, auditors' qualified opinions on related party transactions play a very limited role (Jiang, et al. 2005), new rules related to their activity, as well as increased disclosure requirements, will probably never achieve any result.

In this different context, the introduction of effective regulatory enforcement actions becomes the main issue; they are an unavoidable ancillary measure devised to ensure the effectiveness of stricter disclosure or monitoring requirements.

\section{Complementarities between corporate governance practices}

Solutions consistent with national and social contexts and independent directors, hopefully qualified or professionally backed, are necessary steps in an overall strategy intended to cope with the problem. These steps, however, might not suffice., Any approach should take into account the unavoidable complementarities existing between governance mechanisms in order to increase the probability of being effective and to allow a better assessment of costs and benefits associated with implemented measures.

In fact, not rarely, increased disclosure and more (or deeper) control procedures are associated, in the common perception, to better information and control. Therefore, a natural impetus towards the introduction of new requirements can be observed as a response to specific problems. However, more detailed requirements do not necessarily imply more effective control if they result to be inconsistent with the existing bundle of governance mechanism (Walsh and Seward 1990). Related party transactions often constitute frequent and complex dealings. Increasing levels and wider scopes of disclosure and control lead to new costs, additional risks and possible counter effects. A more complex reporting and control system may introduce uncertainties and organization costs for their implementation and its outcomes and perceived usefulness may be below expected levels whenever it shows a low degree of adaptability with the overall bundles of governance mechanisms (Hoskisson et al. 2009). 
A more detailed related party disclosure, for example, represents an effective solution only if it is adopted within a highly consistent system of governance instruments - such as dispersed ownership, active institutional investors, and market for professional managers (Aguilera et al. 2008). Similarly, in order to conveniently decrease expropriation risks associated with RPTs, a more intense monitoring activity by independent directors requires effective communication mechanisms between the board of directors and the investors and a strong legal protection of shareholders rights (Kim et al. 2006). In addition, more binding requirements (such as board/assembly approval) will probably lead the reporting entities to hide the relations among the counterparts or appoint a trustee, causing a rise in monitoring costs if these instruments are not followed by a concomitant strengthening of the audit procedures (Moyes 2008; Beasley et al. 2001).

In other words, the effectiveness/efficiency of RPTs disciplines may depend on the presence of other governance factors. While the specification of all the possible combinations is beyond the scope of this paper, it is important to underlined that results associated with peculiar RPTs rules might not be fully satisfactory or might not reach the planned targets or even turn out to be negative, if such rules are considered in isolation from other governance practices.

Thus, more binding requirements, often suggested in recent rules and codes, do not necessarily represent the best policy. Accounting overload may be introduced, thereby reducing the actual information relevance of the additional disclosure. Stricter rules may neglect social and governance peculiarities as well as the economic and opportunity costs introduced.

Even in an agency perspective "owners minimize agency costs by balancing the cost monitoring, the cost of risk shifting, and the cost of unsolved agency problems" (Tosi 2008, p. 155). Therefore, monitoring costs cannot be ignored and "black" areas may also be accepted, as additional costs are not outweighed by assumed benefits.

\section{Regulatory implications}

The more contextualized approach to RPTs discipline proposed above raises some important public policy issues and encourages reflecting on the consequent regulatory implications.

In particular, the awareness about a coexistence of theoretical frameworks (conflict of interests and the efficient transactions hypothesis) considered as mutually exclusive so far implies a few preliminary conclusions:

- disclosure can no longer play the central role still granted in recent rules or codes as monitoring should prevail and disclosure should progressively focus on monitoring policies and procedures rather than transactions. The large number and variety of possible dealings favour an overload risk or, in any case, reduce expected utility. Only the description of implemented policies and procedures allows a proper evaluation of their thoroughness. Moreover, with efficient policies fraud risk is reduced and external disclosure may be consistently restricted to few cases; 
- regulators and overseers should be concerned with keeping new disclosure and monitory rules aligned with expected benefits. In fact, as additional disclosure and monitoring bring about further costs and increased complexity, but with uncertain benefits, they should be limited only to transactions that may be considered: (a) relevant, on the basis of their potential impact on figures like turnover, total asset or net worth; (b) not carried out at market price, or, because such reference may lack or not be easily ascertainable, with a price significantly different from fair value; and (c) unusual for the company. Dealings with investments or with business partners, for example, deserve special attention only when not consistent with both the counterparts' activity or significantly different from market conditions, or when the related entity is not audited. ${ }^{14}$ Such distinction is not frequent and usually related parties are considered as a whole group. Moreover, IASB has never accepted suggestions from ASB to differentiate disclosure according to the kind of transactions (limiting it only to abnormal transactions) or to the subjects involved;

- disclosure and monitoring should be limited to material transactions. Ratios, based on comparison to figures like turnover, assets, etc., may be properly applied in order to check their relevance and, indeed, they tend to be more easily found in most recent rules or codes.

Moreover, the idea that RPTs consequences have to be interpreted through the lens of contingent factors, such as organizational context and institutional environments, and that the RPTs discipline should be examined in relation to the overall bundle of governance mechanisms affects potential regulatory models by decreasing the benefits associated with the recent trends towards a standardization and harmonization of RPTs rules. At this regard, few examples may be helpful:

- Organizational Context. In public traded firms, minority shareholders and social implications make stricter rules unavoidable, but when these features lack or are less important, space for lighter solutions should remain. In practice, private companies as well those listed in markets where only professional investors may participate justify a different approach. Conversely, with regard to related party transactions, standard setters and regulators require for private companies and SMEs even more detailed disclosure ${ }^{15}$;

- Institutional Environment. Solutions should take into account probability of risk and related harm. Limiting disclosure and granting exemptions to some subjects, may be justified only on the grounds of limited exposure to the perceived risk. Therefore, exemption for a State agency or State-owned companies may be reasonable in some countries but probably not advisable in others (for instance,

\footnotetext{
14 Significant dealings not in the ordinary course of business with entities not audited or audited by another firm rank among the highest risk factors (Wilks and Zimbleman 2004).

15 For example, the London Stock Exchange's international market for SMEs (A.I.M.) demands disclosure for all related party transactions exceeding certain levels (AIM Rules for Companies, February 2010). Similarly, considering that private companies often obtain capital from shareholders, directors and suppliers as an alternative to the public capital markets, either the IASB or the ASB expand related party disclosure requirements whenever a small-medium enterprise is involved in similar transactions (IASB, IFRS for SMEs, July, 2009; ASB, FRSSE, April, 2008).
} 
like China, where state companies are active players in tunneling, earnings management, etc.). By contrast, the IAS 24 exposure draft, in response to Chinese pressures, reintroduces an exemption from disclosure for all transactions between state-controlled entities);

- Complementarities/Substitution. Where the same transaction is already ruled by specific requirements, related party transaction discipline must not introduce redundant disclosure or duplicate existing rules (i.e. directors' remuneration). At the same time, an effective/efficient RPTs regulation should always consider the complementarities with the other corporate governance tools in order to enhance the usefulness of the overall governance practices.

Such a brief analysis highlights how policy makers should not assume that transferring "best practice" from one regime to another will lead to the same outcomes. The search for more effective measures cannot disregard social factors and governance models, while an examination of the existing legal framework designed to protect investors is essential to alleviate the risk of inconsistencies and to increase the efficiency of the proposed solutions.

\section{Conclusions and implications for future research}

Related party transactions are a complex issue. The prevailing theories tend to describe them as harmful transactions (conflict of interests hypothesis) or, alternatively, as sound economic exchange (efficient transactions hypothesis). However, a deep examination of the articles published on this topic and a critical analysis of the empirical evidence collected so far highlight the existence of important inconsistencies in both the above-mentioned theories.

In actual fact, RPTs cannot be classified only as dealings serving fraudulent or deceptive purposes since they may also fulfil sound economic needs. Consequently, more binding disclosure and monitoring requirements may not achieve the expected results while introducing increased costs and complexity. On the other hand, the idea that related party transactions always represent efficient contracting arrangements carried out to decrease transaction costs might be quite naïve, calling for a deregulated environment that could ignore risks associated with these dealings and undermine confidence in the capital market.

By embracing a contingency framework, this paper describes RPTs as dealings that may fulfil sound business needs as well as be intended for deceptive or fraudulent purposes and stresses the fundamental role that firm's internal and external factors plays in shaping nature and purposes of similar transactions. Consequently, it is asserted that any a priori theoretical scheme aiming at ruling RPTs will always be biased and lead to unsatisfactory disclosure or monitoring solutions.

Indeed, the adoption of a contingency perspective implies an overlap of the theoretical frameworks represented by the conflict of interests and the efficient transactions hypothesis, and obliges to interpret RPTs through the lens of contingent factors concerning specific organizational contexts and institutional environments. 
Moreover, by suggesting an assessment of RPTs discipline in accordance to the bundle of existing governance mechanisms, a complementarity/substitution framework has also been proposed.

These findings have important implications for future researches on RPTs.

In actual fact, researchers should beware of assuming that empirical evidence collected through an examination of a specific institutional setting could be automatically replicated in a different environment. In fact, any in-depth interpretation about the nature and purposes behind RPTs requires a previous analysis of country and firm-level contingencies - such as stages in the organizational life cycle, level of industry-complexity, and strategic environment-and a clear understanding of the influence that these factors might exercise over similar transactions. For these reasons, future studies should differentiate between the role played by RPTs in diverse forms of organizations, or across industries and countries. In addition, papers published so far have focused their attention on RPTs rules effects without taking into account complementarities between governance mechanisms and considering the risk of a potential overlap with already existing disciplines. Future researches should assess the effectiveness/efficiency degree of their proposals by interpreting RPTs disciplines within the bundle of governance mechanisms.

\section{References}

Aguilera, R. V., \& Jackson, G. (2003). The cross-national diversity of corporate governance: Dimensions and determinants. Academy of Management Review, 28(3), 447-465.

Aguilera, R. V., Filatotchev, I., Gospel, H., \& Jackson, G. (2008). An organizational approach to comparative corporate governance: Costs, contingencies, and complementarity. Organization Science, 19(3), 475-492.

Aharony, J., Yuan, H., \& Wang, J. (2005). Related party transactions: A "real” means of earnings management and tunneling during the IPO process in China. Working paper, Singapore Management University.

Bae, K. H., Kang, J. K., \& Kim, J. M. (2002). Tunneling or value addition? Evidence from Mergers by Korean business groups. Journal of Finance, 57(6), 2695-2740.

Barth, M. (1994). Fair value accounting: Evidence from investment securities and the market valuation of banks. The Accounting Review, 69(1), 1-25.

Bauwhede, H. V., \& Willekens, M. (2008). Disclosure on corporate governance in the European Union. Corporate Governance, $16(2)$.

Beasley, M., Carcello, J., \& Hermanson, D. (2001). Top 10 audit deficiencies-SEC sanctions. Journal of Accountancy, 191(4), 63-67.

Bell, T., \& Carcello, J. (2000). A decision aid for assessing the likelihood of fraudulent financial reporting. A Journal of Practice \& Theory, 19(1), 169-184.

Berle, A., \& Means, G. (1932). The modern corporation and private property. New York: Macmillan.

Bertrand, M., Mehta, P., \& Mullainathan, S. (2002). Ferreting out tunneling: An application to Indian business groups. Quarterly Journal of Econmics, 117(1), 121-148.

Brown, A. K. (1980). Background paper on related party transactions, Institute of certified accountants of England and Wales.

Bruce, A., Buck, T., \& Main, B. (2005). Top executive remuneration: A view from Europe. Journal of Management Studies, 42(7), 1493-1506.

Buck, T. W., \& Shahrim, A. (2005). The translation of corporate governance changes across national cultures: The case of Germany. Journal of International Business Studies, 36, 42-61. 
Chang, S. J., \& Hong, J. (2000). Economic performance of group-affiliated companies in Korea: Intragroup resource sharing and internal business transactions. Academy of Management Journal, 43(3), 429-448.

Chen, Y. M., \& Chien, C. Y. (2004). Monitoring mechanism, corporate governance and related party transactions. Working paper, Rutgers University.

Cheung, Y. L., Rau, P. R., \& Stouraitis, A. (2006). Tunneling, propping and expropriation: Evidence from connected party transactions in Hong Kong. Journal of Financial Economics, 82(2), 343-386.

Claeessens, S., \& Fan, J. P. H. (2002). Corporate governance in Asia: A survey. International Review of Finance, 3(2), 71-103.

Claessens, S., Fan, J. P. H., \& Lang, L. H. P. (2006). The benefits and costs of group affiliation: Evidence from East Asia. Emerging Markets Review, 7(1), 1-26.

Coase, R. H. (1937). The nature of the firm. readings in price theory. Il Irwin: Homewood. V.

Coffee, J. C. Jr. (2005). A theory of corporate scandals: Why the US and Europe Differ. The center for law and economic studies, working paper No. 274.

Dedman, E., \& Filatotchev, I. (2008). Corporate governance research: A contingency framework. International Journal of Managerial Finance, 4(4), 248-258.

Denis, D., \& Sarin, A. (1999). Ownership and board structures in publicly traded corporations. Journal of Financial Economics, 52, 187-223.

Di Carlo, E. (2007). Governance e trasparenza del conflitto di interessi nei gruppi aziendali. Roma: Aracne.

Djankov, S., La Porta, R., Lopez-de-Silanes, F., \& Shleifer, A. (2005). The law and economics of selfdealing. NBER working paper No. 11883.

Emshwiller, J. (2003). Many companies report transactions with top officials. The Wall Street Journal, 29(1).

Enriques, L., \& Volpin, P. (2007). Corporate governance reforms in continental Europe. Journal of Economic Perspectives, 21(1), 117-140.

Erickson, M., Mayhew, B., \& Felix, W., Jr. (2000). Why do audits fail? Evidence form Lincoln savings and loan. Journal of Accounting Research, 38, 165-194.

Fama, E. (1980). Agency problems and the theory of the firm. Journal of Political Economy, 88, $288-307$.

Fama, E., \& Jensen, M. (1983). Separation of ownership and control. Journal of Law and Economics, 26, 301-325.

Fan, J. P. H., \& Goyal, V. K. (2006). On the patterns and wealth effects of vertical mergers. Journal of Business, 79(2), 877-902.

Filatotchev, I., \& Wright, M. (2005). Corporate governance life-cycle. London: Edward Elgar.

Filatotchev, I., Toms, S., \& Wright, M. (2006). The firm's strategic dynamics and corporate governance Lyfe cycle. International Journal of Managerial Finance, 2(4), 256-279.

Fisman, R., \& Khanna, T. (2004). Facilitating development: The role of business groups. World Development, 32(4), 609-629.

Friedman, E., Johnson, S., \& Mitton, T. (2003). Propping and tunneling. Journal of Comparative Economics, 31(4), 732-750.

Goodman, H., \& Lorensen, L. (1985). Updated version of illustration of the disclosure of related party transactions. American Institute of Certified Public Accountants.

Gordon, E., \& Henry, E. (2005). Related party transactions and earnings management. Working paper, Rutgers University.

Gordon, E., Henry, E, \& Palia, D. (2004a). The determinants of related party transactions and their impact on firm value. Working paper, Rutgers University.

Gordon, E. A., Henry, E., \& Palia, D. (2004b). Related party transactions and corporate governance. Corporate Governance, 9, 1-27.

Gospel, H., \& Pendleton, A. (2005). Corporate governance and labour management: An international comparison. Oxford, UK: Oxford University Press.

Harris, T., \& Ohlson, J. (1987). Accounting disclosures and the market's valuation of oil and gas properties. The Accounting Review, 62(4).

Hoskisson, R. E., Hitt, M. A., Johnson, W., \& Grossman, W. (2002). Conflicting voices: The effects of institutional ownership heterogeneity and internal governance on corporate innovation strategies. Academy Management Journal, 45, 697-716.

Hoskisson, R. E., Castleton, M. W., \& Withers, M. C. (2009). Complementarity in monitoring and bonding: More intense monitoring leads to higher executive compensation. Academy of Management Perspectives, 23(2), 57-74. 
Huse, M. (2005). Corporate governance: Understanding important contingencies. Corporate Ownership \& Control, 2(4), 41-50.

International Accounting Standard Board, Related Party Disclosures, Nov 2009.

Jensen, M. C., \& Meckling, W. H. (1976). Theory of the firm: Managerial behavior, agency costs and ownership structure. Journal of Financial Economics, 3(4), 305-360.

Jesover, F., \& Kirkpatrik, G. (2005). The revised OECD principles of corporate governance and their relevance to Non-OECD countries. Corporate Governance, 13(2).

Jian, M., \& Wong, T. J. (2003). Earnings management and tunneling through related party transactions: Evidence from Chinese corporate groups. Working paper, The Chinese University of Hong Kong.

Jian, M., \& Wong, T. J. (2004). Earnings Management and tunneling through related party transactions: Evidence from Chinese corporate groups. Working Paper, The Chinese University of Hong Kong.

Jian, M., \& Wong, T. J. (2008). Propping through related party transactions. Review of Accounting Studies (Forthcoming).

Jiang, G., Yue, H., \& Lee, C. M. C. (2005). Tunneling in China: The surprisingly pervasive use of corporate loans to extract funds from Chinese listed companies. Johnson School Research Paper Series, 31-06.

Johnson, R. B., (1997). The board of directors over time: Composition and the organizational life cycle. International Journal of Management, 14, 339-344.

Johnson, S., La Porta, R., Lopez-de-Silanes, F., \& Shleifer, A. (2000). Tunneling. The American Economic Review, 90, 22-27.

Khanna, T., \& Palepu, K. (1997). Why focused strategy may be wrong in emerging markets. Harvard Business Review, 75(4), 41-45.

Khanna, T., \& Palepu, K. (2000). Is group affiliation profitable in emerging markets? An analysis of diversified Indian business groups. The Journal of Finance, 55(2), 867-891.

Kim, K. A., Kitsabunnarat, P., \& Nofsinger, J. R. (2006). Shareholder protection laws and corporate boards: Evidence from Europe, Working Paper.

Klein, A. (2002). Audit committee, board of director characteristics, and earnings management. Journal of Accounting and Economics, 33, 375-400.

Kohlbeck, M., \& Mayhew, B. (2004). Related party transactions. Working Paper, Rutgers University.

La Porta, R., Lopez-de-Silanes, F., Shleifer, A., \& Vishny, R. (1998). Law and finance. Journal of Political Economy, 106, 1131-1155.

La Porta, R., Lopez-de-Silanes, F., Shleifer, A., \& Vishny, R. (1999). Corporate ownership around the world. Journal of Finance, 54, 471-518.

Lemmon, M., \& Lins, K. V. (2003). Ownership structure, corporate governance, and firm value: Evidence from the East Asian Financial Crisis. Journal of Finance, 58, 1445-1468.

Mason, A. K. (1979). Related party transactions: A research study. Toronto: Canadian Institute of Chartered Accountants.

Melis, A. (2005). Corporate governance failures: To what extent is Parmalat a particularly Italian case? Corporate Governance Failures, 13(4), 478-488.

Ming, J. J., \& Wong, T. J. (2003). Earnings management and tunneling through related party transactions: Evidence from Chinese corporate groups. EFA 2003 Annual Conference, Paper No. 549.

Mork, R. (2008). Behavioral finance in corporate governance: Economics and ethics of the Devil's advocate. Journal of Management and Governance, 12(2), 179-200.

Moscariello, N. (2007). Le operazioni tra "parti correlate” nella comunicazione d'azienda. Padova: Cedam.

Moyes, G. D. (2008). CPAs' Perceptions of Red Flags Used in Detecting Fraud. The Icfai Journal of Audit Practice, (1), 48-59.

O.E.C.D. (2004). Principles of corporate governance. Paris: O.E.C.D. Publications.

Rediker, K. J., Seth, A. (1995). Boards of directors and substitution effects of alternative governance mechanisms. Strategic Management Journal, 16, 85-99.

Riyanto, Y. E., \& Toolsema, A. (2004). Tunneling and propping: A justification for pyramidal ownership. Working Paper. National University of Singapore.

Ryngaert, M., \& Thomas, S. (2007). Related party transactions: Their origins and wealth effects. Working Paper. University of Pittsburgh.

Sami, H., \& Schwartz, B. (1992). Alternative pension liability disclosure and the effect on credit evaluation: An experiment. Behavioral Research in Accounting, 4.

Schipper, K. (1989). Commentary on earnings management. Accounting Horizons, 91-102. 
Schmidt, R. H., \& Spindler, G. (2004). Path-dependence and complementarity in corporate governance. In J. N. Gordon \& M. J. Roe (Eds.), Convergence and persistence in corporate governance (pp. 114-127). Cambridge, UK: Cambridge University Press.

Shastri, K., \& Kahle, K. (2004). Executive loans. Working Paper, University of Pittsburgh.

Sherman, H. D., \& Young, S. D. (2001). Accounting Minefields. Harvard Business Review, 129-135.

Swartz, M., \& Watkins, S. (2003). Power failure: The insider story of the collapse of Enron. New York: Doubleday.

Tague, M. (2004). Secrets of the vault. Barons, 13.

Tosi, H. L. Jr. (2008). Quo Vadis? Suggestions for future corporate governance research. Journal of Management and Governance, 12(2), 153-169.

Vicknair, D., Hickman, K., \& Carnes, K. (1993). A note on audit committee independence: Evidence from the NYSE on "Grey" area directors. Accounting Horizons, 7, 53-57.

Walsh, J. P., \& Seward, J. K. (1990). On the efficiency of internal and external corporate control mechanisms. Academy of Management Review, 15(3), 421-458.

Weisbach, M. (1988). Outside directors and CED turnover. Journal of Financial Economics, 20, 431-460.

Wilkins, T., \& Zimmer, I. (1983). The effect of leasing and different methods of accounting leases on credit evaluations. The Accounting Review, 58(4), 749-764.

Wilks, T. J., \& Zimbleman, M. F. (2004). Decomposition of fraud-risk assessments and auditors' sensitivity to fraud cues. Contemporary Accounting Research, 21(3), 719-745.

Williamson, O. (1985). The economic institutions of capitalism: Firms, markets, relational contracting. New York: Free Press.

\section{Author Biography}

Michele Pizzo (born 1962) is full professor of Business Administration and Financial Accounting at the University of Naples II and Program leader at the Link University of Rome. He has spent several months as a visiting professor at the University of Sydney, Gent and Goteborg. He has published about 10 books and several articles in referred journals. He has many conference presentations. His research interests embrace fair value accounting, bank regulation and practice and corporate governance. 